\title{
The financial analysis for the advisability of the biogas project from cattle manure in household scale
}

\author{
Muhammad Mundzir Kamiluddin ${ }^{1}$, Emil Budianto ${ }^{2, *}$, and Evi Frimawaty ${ }^{2}$ \\ ${ }^{1}$ Magister Programme, School of Environmental Science Indonesia University, Jakarta, Indonesia \\ ${ }^{2}$ Lecturer, School of Environmental Science Indonesia University, Jakarta, Indonesia
}

\begin{abstract}
The existence of domestic cattle breeders is a community group that has considerable potential to develop renewable energy resources and environmentally friendly. The methane gas $\left(\mathrm{CH}_{4}\right)$ produced by cattle manure is a strong greenhouse gas, about 25 times stronger than $\mathrm{CO}_{2}$ if organic waste is not taken up and letting it decay in the open, methane causing global warming. This research is to study the feasibility of processing of domestic cattle manure into biogas with financial analysis. The method used is to analyze the financial aspect by calculating NPV, IRR, and B/C Ratio. This research shows that the potential of raw material of biogas at the research location is great. The utilization of biogas from cattle manure on the household scale is financially feasible, as evidenced by its NPV value indicates $>0$, its IRR exceeds the interest rate, and its $\mathrm{B} / \mathrm{C}$ Ratio $>1$, and the majority of breeders also want to process their cattle manure into biogas.
\end{abstract}

\section{Introduction}

Based on the explanation from the National Energy Board in Indonesia's Energy Outlook 2016, Indonesia's energy oil and gas supply continue to decline every year, proven since 2014 oil reserves amounted to 3.6 billion barrels, natural gas amounting to $100.3 \mathrm{TCF}$ and coal reserves of 32.27 billion tons [1]. The Fossil energy has been a driver of Indonesia's past and present economic growth, so it is expected that the trend of energy development would lead to renewable energy in the future. This is because fossil energy is an unrenewed and not environmental friendly resource that will gradually run out, despite the potential for renewable energy resources in Indonesia is big [2]. Therefore, Long-term solutions should be proposed to reduce dependence on non-renewable energy sources [3], and one of them is to look for alternative energy from the renewable and local-based resources that easily produced in a household scale, also has an economical and environmentally friendly value [4]. In addition, this is also in line with the 7th goal of Sustainable Development Goals (SDG's) on clean and affordable energy.

One of the ways that can be done is to install and develop biogas installations in areas that have large cattle breeders, where cattle manure which initially only considered waste that often pollutes the environment can be used as the main ingredient [4]. Biogas is a gas

*Corresponding author: emilb@ui.ac.id 
that can be used as a fuel which consists of a mixture of 65 percent elements of methane $\left(\mathrm{CH}_{4}\right)$ and 35 percent of elements of carbon dioxide $\left(\mathrm{CO}_{2}\right)$. Biogas is renewable energy that can be utilized which is produced from cattle manure [5].

In Indonesia, the livestock centers in the provinces of East Java, West Java, Bali, Sulawesi, Nusa Tenggara, and other provinces have naturally contributed to the acceleration of global warming through the waste produced. However, the processing of livestock manure will automatically convert methane and carbon which act as pollutants into renewable energy which has many benefits for the community [6]. Besides, the development and utilization of biogas is also very instrumental in increasing energy access and supply for the community and contributing to efforts to reduce greenhouse gas emissions, reducing environmental pollution, improving the economy of the community, and improving the health and welfare of the community. Methane gas $\left(\mathrm{CH}_{4}\right)$ produced by cattle manure is a very strong greenhouse gas, about 25 times stronger than carbon dioxide $\left(\mathrm{CO}_{2}\right)$, if the methane is not collected from organic waste and let the waste decompose in the open, it can cause global warming [7].

Methane gas produced from cattle manure contains considerable energy if it is appropriately processed [7]. According to a report from the Ministry of Agriculture of the Republic of Indonesia, in 2017 the largest population of beef cattle and dairy cattle was East Java Province [8]. In that year the number of the beef cattle population in East Java reached $4,534,460$, the second largest province was Central Java with 1,682,449. As for dairy cattles in East Java, there were 264,905 tails and followed by Central Java Province with 137,434 tails. Based on information from the Ministry of Energy and Mineral Resources, 1 cattle produces $15 \mathrm{Kg}$ of manure on average, every $25 \mathrm{Kg}$ of cattle manure can produce $1 \mathrm{~m}^{3}$ of biogas, and $1 \mathrm{~m}^{3}$ of biogas is equivalent to 0.62 liters of kerosene or $0.46 \mathrm{~kg}$ of LPG [5].

Information from the Ministry of Energy and Mineral Resources, the current government program for the development of biogas is the Home Biogas Program (BIRU) [5]. The BIRU program provides cash assistance of 2 million and is also a facilitator to help farmers get loan funds from financial institutions that are BIRU Program partners for biogas development. However, those who get loan assistance are dairy farmers, because the benefits are amount and time. In the research location, there were household-scale beef cattle farmers, so it was difficult to get assistance for the construction of biogas installations. This is an interesting topic to be studied regarding its feasibility for biogas development because the initial capital needed to develop biogas is large.

\section{Method}

This research was conducted in Sopet Village, Jangkar Subdistrict, Situbondo Regency, Indonesia. The location was selected because for it is one of the largest home-based beef cattle population in Situbondo [9]. Data collection is carried out using interviews, observations, and literature studies. There are three aspects examined in this study, economic feasibility aspects and the social aspect is the willingness of the community.

The assessment of economic feasibility aspects using Net Present Value (NPV), Internal Rate of Return (IRR), and Benefit-Cost Ratio (B/C Ratio) calculations. The NPV is the difference between disbursed expenditure and income by using the social opportunity cost of capital as a discount factor, or a cash flow that is estimated to be discounted in the future at this time. To calculate NPV data is needed about the estimated investment costs, operating costs, and maintenance as well as estimates of the benefits of the planned project. The data for each variable used in calculating economic feasibility are obtained from literature studies and interviews with respondents. The general formula used in NPV is:

$$
N P V=\sum_{t=0}^{T}\left(B_{t}-C_{t}\right) \times \frac{1}{(1+r)^{t}}
$$


Information:

$\mathrm{r}=$ interest rate

$\mathrm{t}=$ year from 0 to $\mathrm{T}$

IRR is a discount rate that makes NPV equal to zero but has nothing to do with the discount rate which is calculated based on data outside the project as a social opportunity cost of capital that is generally applicable in the community (deposit interest). To calculate the previous IRR, a discount rate must be found which produces a positive NPV, then a discount rate is found which produces a negative NPV. The next step is to interpolate with the following formula:

$$
I R R=i_{1}+\frac{N P V_{1}}{N P V_{1}-N P V_{2}}\left(i_{2}-i_{1}\right)
$$

Information:

$\mathrm{i}_{1} \quad=$ Discount rate that produces a positive NPV

$\mathrm{i}_{2}=$ Discount rate that produces a negative NPV

$\mathrm{NPV}_{1}=$ Net Present Value has a positive value

$\mathrm{NPV}_{2}=$ Net Present Value has a negative value

$\mathrm{B} / \mathrm{C}$ Ratio is the value of benefits that can be obtained from a project or business every time we spend a fee of one rupiah for the project or business. B/C Ratio is a comparison between a positive NPV and a negative NPV. Common formulas commonly used are as follows:

$$
\frac{B}{C}=\frac{\sum_{t=0}^{T}\left\{B_{t} /(1+r)^{t}\right\}}{\sum_{t=0}^{T}\left\{C_{t} /(1+r)^{t}\right\}}
$$

Information:

$\mathrm{r}=$ interest rate

$\mathrm{t}=$ year from 0 to $\mathrm{T}$

To find out the social aspects in the form of the willingness of the community to process their cattle manure into biogas is done by determining several research variables, including the level of education, employment, income, and the number of cattles maintained. The data is generated by interviewing respondents using a questionnaire. After the data is collected then processed using SPSS software by using the Chi-Square test to see the relationship between the social characteristics of farmers and the willingness to process their cattle manure into biogas. If the test results get P-Value less than 0.05 , there is a relationship, and the magnitude of the relationship is seen from the OR value generated.

\section{Result and discussion}

\subsection{Biogas potential in research sites}

Based on data from BPS Situbondo Regency, the Sopet Village is one of the villages with the highest population of beef cattle in Situbondo with the number of cattles reaching 5,845 and the number of breeders as many as 1,948 people, so that one farmer on average has or maintains about 3 cattles.

The amount of cattle manure produced every day depends on the age, based on one study the amount is between $6.5 \mathrm{~kg}$ to $25 \mathrm{~kg}$ (table 1).

Table 1. Number of Cattle Manure by Age Group.

\begin{tabular}{|c|c|}
\hline Age Group & Number of Cattle Manure (kg/day) \\
\hline Adult & 25 \\
\hline
\end{tabular}




\begin{tabular}{|c|c|}
\hline Teenager & 12,5 \\
\hline Children & 6,5 \\
\hline
\end{tabular}

Source: Asmara et al., 2013 [10]

From $25 \mathrm{~kg}$ of cattle manure can produce $1 \mathrm{~m}^{3}$ of biogas that will be equivalent to 0.62 liters of kerosene or $0.46 \mathrm{~kg}$ of LPG [5]. Therefore, the biogas potential per day at the location is equivalent to $1,613 \mathrm{~kg}$ LPG or equivalent to 2,174 liters of kerosene, see table 2 .

If calculated by the cheapest LPG price (i.e., $3 \mathrm{~kg}$ LPG tubes) which around IDR 18,000 per tube, if the consumption is equivalent to 538 tubes, it would be estimated approximately IDR 9,684,000 per day or IDR 290,520,000 per month.

Table 2. Potential of Biogas into LPG and Kerosene in Study Location.

\begin{tabular}{|c|c|c|c|c|c|c|}
\hline \multirow{2}{*}{$\begin{array}{c}\text { Total of } \\
\text { Breeders } \\
\text { (person) }\end{array}$} & \multirow{2}{*}{$\begin{array}{l}\text { Total of } \\
\text { Cattle } \\
\text { (cattle) }\end{array}$} & \multirow{2}{*}{$\begin{array}{c}\text { Total of } \\
\text { Manure } \\
(\mathrm{kg})\end{array}$} & \multirow[b]{2}{*}{$\begin{array}{c}\text { Total of } \\
\text { Biogas }\left(\mathrm{m}^{3}\right)\end{array}$} & \multicolumn{2}{|c|}{ Conversion Result } & \multirow[b]{2}{*}{$\begin{array}{l}\text { Price of LPG } \\
\text { (Rp. } 6000,-/ \mathrm{kg} \text { ) }\end{array}$} \\
\hline & & & & $\begin{array}{l}\text { LPG } \\
(\mathrm{kg})\end{array}$ & $\begin{array}{l}\text { Kerosene } \\
\text { (liter) }\end{array}$ & \\
\hline 1,948 & 5,845 & 87,675 & 3,507 & 1,613 & 2,174 & $9,678,000$ \\
\hline 1 & 3 & 45 & 1.8 & 0.83 & 1.12 & 4,980 \\
\hline
\end{tabular}

The result shows that the average usage of $3 \mathrm{~kg}$ LPG for cooking purpose in each household last for 5 days or equivalent to $0.6 \mathrm{~kg}$ LPG per day. With the calculation of each farmer that has average ownership for 3 cattles will produce cattle manure based biogas that equivalent to $0.83 \mathrm{~kg}$ of LPG per day (table 2), which already exceeds the requirements for the daily necessities. Kerosene was not calculated due to the unavailable supply in the location.

\subsection{Financial feasibility analysis}

For the result of NPV calculation, if the NPV is greater than zero (NPV $>0$ ) which means that the business or project is profitable or beneficial. Whereas if a business has an NPV smaller than zero $(\mathrm{NPV}<0)$ then the business is not feasible to run [11]. For IRR valuation, an investment is considered feasible if the IRR value is higher than the prevailing interest rate and is not feasible if the IRR value is less than the prevailing interest rate [12]. Whereas for B/C Ratio the conditions are as follows [13]:

1. The value of $\mathrm{B} / \mathrm{C}$ Ratio $>1$, it means that the project is worthy of being run financially.

2. The value of $\mathrm{B} / \mathrm{C}$ Ratio $<1$, it means that the project is not feasible to run financially.

\subsubsection{Inflow}

The revenue obtained from biogas processing per farmer is the result of the biogas produced is converted to the price and type of LPG that is used by the community at the research site. Therefore, each farmer income from the produced biogas is IDR 1,798,800 per year.

\subsubsection{Outflow}

Expenditures incurred by each farmer to develop and carry out biogas processing include investment costs, operational costs. Each farmer needs IDR 5,700,000 for the investment costs [14], but with the assistance of Blue Program about IDR 2,000,000 for each biogas digester making, the investment cost for each farmer reduced to IDR 3,700,000. For operational costs of IDR 300,000 per year for the purchase of a starter. The type of digester used has a service life of around 15 years [5]. 


\subsubsection{Financial feasibility analysis}

The financial feasibility analysis is carried out using an interest rate of $17 \%$ which is the average interest rate in several government banks during the period 2018. This criterion is carried out to see how far the project is feasible if the farmer uses the loan capital from the existing Government Bank. With cash flow at a $17 \%$ interest rate, the financial feasibility is analyzed based on predetermined criteria. Table 3 shows that the results of the financial feasibility analysis of the biogas development program at an interest rate of $17 \%$.

Table 3. Financial feasibility analysis result.

\begin{tabular}{|c|c|}
\hline Financial Feasibility Criteria & Result \\
\hline NPV & IDR $1,234,238$ \\
\hline IRR & $23 \%$ \\
\hline B/C Ratio & 2.6 \\
\hline
\end{tabular}

From table 3, it can be seen that the results of the NPV calculation from the biogas installation project amounted to IDR $1,234,238$. This means that the present value of the income earned is positive for 15 years with an interest rate of $17 \%$, which is feasible to be carried out at the research site. IRR calculation results show the value obtained is $23 \%$. The ability of the project to return the capital used is higher than the prevailing interest rate of $17 \%$. This means that the IRR value obtained by this project is financially feasible. Table 3 also shows the value of the $\mathrm{B} / \mathrm{C}$ ratio generated with a $17 \%$ interest rate is 2.6 . This value indicates that each expenditure of IDR 100 will generate benefits of IDR 260 and it can be said that net income obtained is 2.6 times the costs incurred.

\subsection{Community social conditions}

The social condition of the community in question is the willingness of farmers to develop biogas processing installations from the cattle manure they maintain. This breeders' willingness is seen from some of the social characteristics which include the level of education, knowledge, occupation, income, and the number of cattles kept [15]. From these variables, it was found that the social conditions associated with the willingness or willingness of the community to develop biogas installations were the number of cattles they maintained, the resulting P-Value was 0.005 (see table 4). Statistical test results show that farmers who have cattles at least 3 head have a 2.962 (OR) opportunity to develop biogas plants compared to farmers who have cattles less than 3 .

Table 4. Community Attitudes Based on Social Characteristics $(n=150)$.

\begin{tabular}{|c|c|c|c|c|c|c|c|c|c|}
\hline \multirow{3}{*}{\multicolumn{2}{|c|}{ Variable }} & \multicolumn{4}{|c|}{ Community Attitude } & \multirow{2}{*}{\multicolumn{2}{|c|}{ Total }} & \multirow{3}{*}{$\begin{array}{c}\mathrm{P} \\
\text { Value }\end{array}$} & \multirow{3}{*}{ OR } \\
\hline & & \multicolumn{2}{|c|}{ Willing } & \multicolumn{2}{|c|}{ Not Willing } & & & & \\
\hline & & $\mathrm{n}$ & $\%$ & $\mathrm{n}$ & $\%$ & $\mathrm{~N}$ & $\%$ & & \\
\hline \multirow[t]{2}{*}{ Education } & - High & 8 & 57.1 & 6 & 42.9 & 14 & 100 & \multirow[t]{2}{*}{1.00} & \multirow{2}{*}{$\begin{array}{c}0.991 \\
(0.326-3.014)\end{array}$} \\
\hline & - Low & 78 & 57.4 & 58 & 42.6 & 136 & 100 & & \\
\hline \multirow{2}{*}{$\begin{array}{l}\text { Understan } \\
\text { ding }\end{array}$} & - Understand & 14 & 70.0 & 6 & 30.0 & 20 & 100 & \multirow[t]{2}{*}{0.323} & \multirow{2}{*}{$\begin{array}{c}1,880 \\
(0.680-5.197)\end{array}$} \\
\hline & - Not Understand & 72 & 55.4 & 58 & 44.6 & 130 & 100 & & \\
\hline \multirow[t]{2}{*}{ Job Status } & - Permanent & 25 & 59.5 & 17 & 40.5 & 42 & 100 & \multirow[t]{2}{*}{0.877} & \multirow{2}{*}{$\begin{array}{c}1.133 \\
(0.549-2.337)\end{array}$} \\
\hline & - Not permanent & 61 & 56.5 & 47 & 43.5 & 108 & 100 & & \\
\hline \multirow[t]{2}{*}{ Income } & $-\geq$ Standard & 24 & 61.5 & 15 & 38.5 & 39 & 100 & \multirow[t]{2}{*}{0.668} & \multirow{2}{*}{$\begin{array}{c}1.265 \\
(0.600-2.666)\end{array}$} \\
\hline & $-<$ Standard & 62 & 55.9 & 49 & 44.1 & 111 & 100 & & \\
\hline \multirow{2}{*}{$\begin{array}{l}\text { Total of } \\
\text { cattle }\end{array}$} & $-\geq 3$ cattles & 69 & 65.1 & 37 & 34.9 & 106 & 100 & \multirow[t]{2}{*}{0.005} & \multirow{2}{*}{$\begin{array}{c}2.962 \\
(1.432-6.124)\end{array}$} \\
\hline & $-<3$ cattles & 17 & 38.6 & 27 & 61.4 & 44 & 100 & & \\
\hline
\end{tabular}


From table 4 it can be inferred that 136 respondents have low education, and 130 respondents did not understand or having knowledge about biogas. As for the employment status, about 108 respondents were mostly working as farm laborers who do not necessarily work every day. Moreover, based on the earnings each month, there were 111 respondents whose income were below the UMR and unsteady every month.

\section{Conclusion}

From the results of this study there are at least 4 points obtained:

1. In the study location, the energy needs for cooking at the research site on average each household is $0.6 \mathrm{~kg}$ of LPG per day, while the biogas energy potential that can be produced is equivalent to $0.83 \mathrm{~kg}$ of LPG per farmer every day.

2. Financial analysis using NPV, IRR, and B/C ratio calculations shows that the development of a biogas installation on a household scale with a $4 \mathrm{~m}^{3}$ digester is feasible.

3. The social condition of the community which is related to the willingness to develop the biogas plant is the number of cattles kept, the breeder who maintain a minimum of 3 cattles is willing to make biogas installation.

\section{References}

1. E. Prasodjo, H. Nurzaman, Walujanto. Indonesia Energy Outlook 2016 (in bahasa Indonesia) (2016)

2. N. Indrawan, S. Thapa, M.E. Wijaya, M. Ridwan, D.H. Park, J. Env. Dev. 25, 85-99 (2017)

3. Teodorita, D. Rutz, H. Prassl, M. Köttner, T. Finsterwalder, S. Volk, R. Janssen, Biogas Handbook (2008)

4. E.R. Abraham, S. Ramachandran, V. Ramalingam, Env. Sci. Poll. Res. Int, 14, 67-71 (2007)

5. Ministry of Energy and Mineral Resources. Waste as a Blessing to Home Biogas Program (BIRU) as Alternative Energy for the Future in Indonesia and Success Stories of its Users (in bahasa Indonesia). (2016)

6. N. Ginting, F. Zuhri, Hasnudi, E. Mirwandhono, I. Sembiring, A.H. Daulay, IOP Conf. Series: Earth and Environmental Science, 122 (2018)

7. T. Abbasi, S.M. Tauseef, S.A. Abbasi, Biogas Energy. SpringerBriefs in Environmental Science, 25 (2012)

8. Ministry of Agriculture. Province of Beef Cattle Population. Directorate General of Livestock and Animal Health (in bahasa Indonesia). (2017)

9. BPS-Statistics Indonesia. Situbondo Regency in Figures 2017 (in bahasa Indonesia). (2017)

10.A. Asmara, M.P. Hutagol, Salundik, Jur.Agri.Ind. 1, 71-80 (2013)

11. G.A. Gebrezgabher, M.P.M. Meuwissen, B.A.M. Prins, A.G.J.M.O. Lansink, J. Li. Sci. 57, 109-115 (2010)

12. M.N. Kaya, F. Kose, E3S Web Conf. 10 (2016)

13. H. Berber, R. Frey, V. Voronova, A. Koroljova, Was. Man. Res. 35, 904-912 (2017)

14. A.S. Bedi, R. Sparrow, L. Tasciotti, J. of Ener. Eco. 68, 66-76 (2017)

15.C.G.M. Garcia, J. Trop. Ani. Hea. Pro. 44, 1199-1211 (2012) 